\title{
PENGUNGKAPAN INFORMASI KEUANGAN SECARA SUKARELA DI INTERNET OLEH PERUSAHAAN BESAR DI INDONESIA
}

\author{
Ernawati dan Hasya Fayiatha* \\ * Jurusan Akuntansi, Fakultas Ekonomi \\ Universitas Internasional Batam \\ Email: Hasyafayiatha@gmail.com
}

\begin{abstract}
The purpose of this study is to examine the impact of characteristics as a potential factor that might influence each financial disclosure on the internet voluntarily by large companies in Indonesia. The characteristic in this study are the company size, leverage, profitability, company age, dispersion ownership, industrial sector, and auditor type. The sample chosen uses a purposive sampling method to collect as many as 414 large companies listed on the Indonesia Stock Exchange in 2013 to 2017. Using binary logistic regression to determine the effect of independent variables on the dependent variables and processed using the program of SPSS version 21.

The results of data analysis and conclusions indicate that the size of the company has a significantly positive effect on Internet Financial Reporting. Variables of company age, industry sector, and auditor type indicate a significantly negative influence. Wheares, for the variables of leverage, profitability, and dispersion of ownership there are no significant findings on Internet Financial Reporting.
\end{abstract}

Keywords: Internet Financial Reporting, company size, leverage, profitability, company age, dispersion of ownership, industry sector, auditor type, binary logistic regression, large companies.

\section{INTRODUCTION}

Kemajuan yang pesat dan semakin meratanya pemakaian internet, perusahaan telah memperoleh media koneksi yang sangat efektif untuk penyajian informasi penting kepada investor dan pemangku kepentingan lainnya (Dolinšek \& LutarSkerbinjek, 2017). Internet Financial Reporting merupakan pemakaian internet digunakan untuk alat penyampaian laporan keuangan perusahaan (Sulistyanto \& Nugrahanti, 2013).

Bollen et al. (2006) mengemukakan bahwa maksud utama dari Internet Financial Reporting harus memberi investor informasi keuangan untuk membuat keputusan alokasi modal. Karakteristik ini telah membuat IFR menjadi praktik umum di negara-negara maju (Pervan, 2006) dan beberapa tahun terakhir juga dilakukan di negara berkembang (Mohamed \& Basuony, 2015).

Tiga keunggulan yang terdapat pada IFR yaitu memudahkan dalam mendapatkan informasi keuangan dan meningkatkan ketepatan waktu, memberikan informasi untuk perusahaan dengan biaya yang lebih murah, dan menyediakan aksesibilitas ke para pengguna tanpa adanya halangan geografis (Xiao et al., 2004). Di sisi lain, masalah keamanan, biaya, dan keahlian adalah kerugian menempatkan informasi keuangan di internet (Khan \& Ismail, 2012). Selain itu, Dolinšek dan LutarSkerbinjek (2017) menyatakan bahwa kerugian lain juga dapat dilihat pada fakta bahwa perusahaan IFR juga beresiko memberikan pengungkapan kepada pesaing, yang memiliki akses ke informasi rinci tentang kinerja perusahaan mereka. 
Maksud penelitian ini yaitu untuk mengetahui contoh perusahaan besar di Indonesia sebagai dasar dan penentuan proporsi perusahaan yang menggunakan situs di Bursa Efek Indonesia untuk mengungkapkan informasi keuangan memakai karakteristik ukuran perusahaan, leverage, profitabilitas, umur perusahaan, kepemilikan dispersi, sektor industri, dan tipe auditor untuk diuji.

\section{LITERATURE REVIEW AND HYPOTHESIS DEVELOPMENT}

Investor dan calon investor harus dengan mudah memperoleh informasi untuk membuat keputusan investasi, perusahaan selalu memilih media baru untuk menyebarluaskan informasi kepada pengguna eksternal, salah satu media yang tersedia di lingkungan adalah teknologi internet (Al Arussi et al., 2009). Berikut penjelasan untuk mengetahui pengaruh tujuh variabel terhadap IFR.

\section{Ukuran Perusahaan}

Biaya agensi menjurus naik dengan ukuran perusahaan sebab perusahaan yang lebih besar mempunyai keliruan lebih banyak informasi antara pemegang saham dan manajer. Sebab itu, perusahaan besar mempunyai insentif yang lebih banyak dalam menggunakan pelaporan internet untuk memberikan informasi tepat waktu kepada pemegang saham dan debt holders untuk mendukung perdagangan saham mereka (Al Arussi et al., 2009). Beberapa penelitian sebelumnya (Dolinšek \& LutarSkerbinjek, 2017; Bowrin, 2015; Mokhtar, 2017) menunjukkan korelasi positif antara ukuran perusahaan dan Internet Financial Reporting.

H1: Ada hubungan positif antara ukuran perusahaan dan Internet Financial Reporting

\section{Leverage}

Posisi manajer perusahaan dapat terancam apabila leverage perusahaan tinggi, dikarenakan hal itu dianggap bahwa manajer tidak dapat menjalankan perusahaan dengan baik (Lestari \& Chariri,
2007). Salah satu cara untuk membantu menyiarkan segala kabar positif perusahaan adalah dengan menerapkan praktik IFR, karena IFR memuat lebih banyak informasi yang bermaksud untuk "mengaburkan" perhatian investor berharap mereka tidak terlalu berpusat pada tingginya leverage yang dimiliki perusahaan. Beberapa penelitian sebelumnya (Mokhtar, 2017; Lestari \& Chariri, 2007; Bollen et al., 2006) menunjukkan korelasi positif antara leverage dan IFR.

$\mathrm{H} 2$ : Ada hubungan positif antara leverage dan Internet Financial Reporting

\section{Profitabilitas}

Teori sinyal memperkirakan bahwa profitabilitas perusahaan yang lebih tinggi akan mengambil keputusan untuk mengungkap kualitas informasi perusahaan karena ingin memperlihatkan kepada investor dan publik, sedangkan perusahaan yang profitabilitasnya lebih rendah akan berusaha menyembunyikan informasi perusahaannya. Oleh karena itu, perusahaan yang menguntungkan dapat memakai pelaporan internet sebagai saluran untuk memfasilitasi proses pensinyalan seperti itu (Marston \& Polei, 2004). Beberapa penelitian sebelumnya (Bowrin, 2015; Aly et al., 2010; Mokhtar, 2017) menunjukkan korelasi positif antara profitabilitas dan Internet Financial Reporting.

H3: Ada hubungan positif antara profitabilitas perusahaan dan Internet Financial Reporting

\section{Umur Perusahaan}

Bowrin (2015) mengemukakan bahwa perusahaan online yang lebih lama mungkin telah mengembangkan pengalaman yang lebih baik dalam menerapkan internet untuk penyebaran informasi perusahaan. Sedangkan perusahaan yang baru berdiri mungkin mengalami kerugian kompetitif yang lebih besar jika laporan keuangan mereka diungkapkan. Sebab itu, perusahaan yang 
berdiri lebih lama mungkin mengungkapkan lebih banyak informasi daripada perusahaan yang baru (Nurunnabi \& Hossain, 2012). Penelitian sebelumnya (Bowrin, 2015) menunjukkan korelasi positif antara umur perusahaan dan Internet Financial Reporting.

H4: Ada hubungan positif antara umur perusahaan dan Internet Financial Reporting

\section{Kepemilikan Dispersi}

Kepemilikan dispersi lebih tersebar pada perusahaan terbuka dimana sahamnya dimiliki oleh 300 pemegang saham daripada perusahaan tertutup dimana perusahaan ini membatasi pemegang sahamnya. Oleh sebab itu, proporsi saham perusahaan yang semakin besar dimana dimiliki oleh masyarakat (publik) diperkirakan pengungkapan informasi keuangan melalui internet akan lebih luas (Suripto, 2006). Beberapa penelitian sebelumnya (Al-Moghaiwli, 2009; Nurunnabi \& Hossain, 2012; Marston \& Polei, 2004) menunjukkan korelasi positif antara kepemilikan dispersi dan Internet Financial Reporting.

H5: Ada hubungan positif antara kepemilikan dispersi dan Internet Financial Reporting

\section{Sektor Industri}

Marston (2003) berpendapat bahwa kesadaran dari teknologi dari beberapa industri, seperti industri "berteknologi tinggi" dapat mempengaruhi pengungkapan. Perusahaan sektor industri dengan teknologi IT canggih dan modal intelektual, misalnya perusahaan teknologi informasi dan komunikasi dan elektronik lebih dipengaruhi oleh lingkungan (Dolinšek \& Lutar-Skerbinjek, 2017). Karena aktivitas bisnis mereka terhubung dengan informasi teknologi, maka mereka lebih rentan terhadap Internet Financial Reporting. Beberapa penelitian sebelumnya (Alanezi, 2009; Aly et al., 2010; Oyelere et al., 2003) memperlihatkan korelasi positif antara sektor industri dan Internet Financial Reporting.

H6: Ada hubungan positif antara sektor industri dan Internet Financial Reporting

\section{Tipe Auditor}

Kualitas audit akan mendorong perusahaan dalam menyiarkan laporan keuangan melalui IFR dan menaikkan nilai perusahaan dalam rangka menggalang kepercayaan investor. Alanezi (2009) mengasumsi bahwa perusahaan audit yang berafiliasi dengan perusahaan audit Big 4 memiliki insentif untuk mendorong perusahaan klien mereka untuk terlibat dalam Internet Financial Reporting. Beberapa penelitian sebelumnya (Mokhtar, 2017; Nurunnabi \& Hossain, 2012; Mohamed \& Basuony, 2015) menunjukkan korelasi positif antara tipe auditor dan Internet Financial Reporting.

H7: Ada hubungan positif antara tipe auditor dan Internet Financial Reporting

\section{RESEARCH METHODOLOGY}

Penggunaan analisis regresi logistik biner yang dipilih untuk penelitian ini dikarenakan adanya dua kriteria pada variabel dependen. Teknik pengumpulan data menggunakan data sekunder yaitu internet research untuk mengakses laporan keuangan di situs www.idx.co.id dari Bursa Efek Indonesia pada tahun 20132017. Penentuan sampel dilakukan menggunakan metode purposive sampling yang memenuhi dua dari kriteria berikut untuk mendefinisikan perusahaan besar di Indonesia, berdasarkan kriteria dari Badan Pusat Statistik dan Badan Standarisasi Nasional (BSN) yaitu jumlah karyawan lebih dari 100 orang, total aset melebihi Rp $10 \mathrm{M}$, dan total pendapatan melebihi Rp 50 M. Sampel yang memenuhi kriteria tersebut sebanyak 414 perusahaan.

\section{Dependent Variables}

Variabel dependen diklasifikasikan sebagai pilihan biner antara perusahaan IFR dan Non IFR. IFR merupakan 
pemakaian internet difungsikan untuk alat penyampaian laporan keuangan perusahaan (Sulistyanto \& Nugrahanti, 2013). Menurut Dolinšek dan LutarSkerbinjek (2017) Internet Financial Reporting diukur menggunakan variabel dummy dimana:

Internet Financial Reporting $=$ variabel dummy jika menerapkan IFR "1" jika tidak " 0 "

\section{Independent Variables}

Variabel independen yang terdapat pada penelitian ini yakni:

1. Ukuran perusahaan

Sumber daya tinggi yang dimiliki perusahaan besar akan berpengaruh bagi pemangku kepentingan karena mereka memerlukan lebih banyak informasi perusahaan untuk mengambil kebijakan investasi yang lebih efektif. Rumus perhitungan ukuran perusahaan (Dolinšek \& Lutar-Skerbinjek, 2017), yaitu:

\begin{tabular}{|l|}
\hline a. Jumlah karyawan $=>100$ orang \\
Menurut Badan Pusat Statistik \\
\hline b. Total aset $=>\operatorname{Rp} 10$ Miliar \\
Menurut Badan Standarisasi Nasional
\end{tabular}
(BSN)

c. Total pendapatan $=>\operatorname{Rp} 50$ Miliar
Menurut Badan Standarisasi Nasional $(\mathrm{BSN})$

\section{Leverage}

Leverage perusahaan menunjukkan kompentensi perusahaan untuk memenuhi semua utang jangka panjangnya (Oyelere et al., 2003). Leverage diukur dari debt to asset ratio dan debt to equity ratio.

\section{a. DAR $=\frac{\text { Total kewajiban }}{\text { Total aset }}$}

Rumus perhitungan debt to asset ratio (Mokhtar, 2017).

b. DER $=\frac{\text { Total kewajiban }}{\text { Total equity }}$

Rumus perhitungan debt to equity ratio

(Mokhtar, 2017).

\section{Profitabilitas}

Profitabilitas perusahaan ditujukan untuk mengetahui perbandingan antara modal yang menghasilkan laba atau antara laba dengan aktiva tersebut. Pengukuran profitabilitas dideskripsikan dari return on equity, return on assets, dan return on sales.

a. $\mathrm{ROE}=\frac{\text { Laba bersih setelah pajak }}{\text { Ekuitas pemegang saham }}$

Rumus perhitungan return on equity (Aly et al., 2010).

b. $\mathrm{ROA}=\frac{\text { Laba bersih setelah pajak }}{\text { Total aset }}$ Total aset

Rumus perhitungan return on assets (Al-Moghaiwli, 2009).

c. $\mathrm{ROS}=\frac{\text { Laba sebelum pajak dan bunga }}{\text { Penjualan }}$

Rumus perhitungan return on sales

(Dolinšek \& Lutar-Skerbinjek, 2017).

\section{Umur perusahaan}

Semakin lama perusahaan berdiri, maka diharapkan perusahaan semakin mengetahui kebutuhan informasi bagi penggunanya. Rumus perhitungan umur perusahaan (Hossain \& Hammami, 2009), yaitu:

Umur perusahaan $=$ Tahun penelitian Tahun perusahaan didirikan

\section{Kepemilikan dispersi}

Kepemilikan dispersi merupakan kepemilikan saham yang tersebar dimiliki oleh investor individu. Rumus perhitungan kepemilkan dispersi (Alsaeed, 2006), yaitu:

\begin{tabular}{|l}
$\begin{array}{l}\text { Kepemilikan dispersi } \\
\text { Jumlah saham yang dimiliki investor individu }\end{array}$ \\
Jumlah saham yang beredar
\end{tabular}$=$

\section{Sektor industri}

Marston (2003) berpendapat bahwa kesadaran dari teknologi dari beberapa industri, seperti industri "berteknologi tinggi" dapat mempengaruhi pengungkapan. Rumus perhitungan sektor industri (Dolinšek \& Lutar-Skerbinjek, 2017), yaitu: 
Sektor industri $=$ variabel dummy jika perusahaan termasuk sektor keuangan, energetik, dan teknologi informasi dan komunikasi "1" jika lainnya " 0 "
7. Tipe auditor

Perusahaan audit internasional lebih cenderung memfasilitasi praktik teori difusi inovasi seperti Internet Financial Reporting (Xiao et al., 2004).

Tipe auditor $=$ variabel dummy jika perusahaan diaudit Big 4"1" jika tidak "0"

\begin{tabular}{|c|c|c|c|c|c|}
\hline \multicolumn{6}{|c|}{$\begin{array}{l}\text { RESEARCH FINDINGS } \\
\text { Descriptive Analysis } \\
\text { Tabel } 1 \\
\text { Descriptive Statistics Results } \\
\end{array}$} \\
\hline Variabel & $\mathbf{N}$ & Minimum & Maksimum & Rata-rata & Std. Deviasi \\
\hline Aset & 2070 & 30772661987 & $\begin{array}{r}1126248442000 \\
000\end{array}$ & $\begin{array}{r}2039193818499 \\
1,18\end{array}$ & $\begin{array}{r}8030101357324 \\
0,940\end{array}$ \\
\hline Pendapatan bersih & 2070 & $\begin{array}{r}- \\
127232937950 \\
00\end{array}$ & $\begin{array}{r}3270100000000 \\
0\end{array}$ & $\begin{array}{r}659465417247,3 \\
4\end{array}$ & $\begin{array}{r}2754051446723 \\
727\end{array}$ \\
\hline Karyawan & 2070 & 52 & 225580 & 4860,40 & 13801,974 \\
\hline DAR & 2070 & ,0008 & 16,8344 & 6089 &, 7314 \\
\hline DER & 2070 & $-31,1754$ & 94,0997 & 1,9536 & 4,0119 \\
\hline ROE & 2070 & $-11,0404$ & 7,9910 & ,0850 & ,4856 \\
\hline ROA & 2070 & $-10,8894$ & 1,1856 & 0220 &, 3344 \\
\hline ROS & 2070 & $-28,2307$ & 15,0928 & ,0102 & 1,1981 \\
\hline Umur & 2070 & 4 & 161 & 34,29 & 17,908 \\
\hline $\begin{array}{l}\text { Kepemilikan } \\
\text { dispersi }\end{array}$ & 2070 &, 0000 & ,9986 & ,2643 & , 1798 \\
\hline Valid N (listwise) & 2070 & & & & \\
\hline
\end{tabular}

Sumber: Data sekunder diolah (2019)

Tabel 1 yang telah diuraikan di atas, memperlihatkan ukuran perusahaan dideskripsikan memakai total aset, pendapatan bersih, serta jumlah karyawan.

Rata-rata nilai total aset yakni sebesar Rp 20.391.938.184.991,18 berarti secara keseluruhan perusahaan telah tergolong perusahaan besar menurut Badan Standarisasi Nasional (BSN), dimana aset perusahaan harus diatas Rp 10 Miliar. PT Red Planet Indonesia Tbk memiliki nilai aset terkecil sebesar Rp 30.772.661.987 di tahun 2013 dan PT Bank Rakyat Indonesia (persero) Tbk memiliki nilai aset terbesar di tahun 2017 dengan total aset Rp 1.126.248.442.000.000. Standar deviasi sebesar Rp 80.301.013.573.240,940 (di atas rata-rata) artinya total aset memiliki tingkat variasi data yang tinggi.

Rata-rata nilai pendapatan bersih adalah sebesar $\mathrm{Rp}$ 659.465.417.247,34 berarti secara keseluruhan perusahaan telah tergolong perusahaan besar menurut Badan Standarisasi Nasional (BSN), dimana 
pendapatan bersih harus diatas $\mathrm{Rp} 50$ Miliar. Nilai pendapatan bersih terkecil pada perusahaan sampel adalah sebesar Rp -12.723.293.795.000 dimana terdapat pada perusahaan Bakrie \& Brothers Tbk pada tahun 2013 dan PT Telekomunikasi Indonesia (Persero) Tbk memiliki pendapatan bersih terbesar di tahun 2017 yang berjumlah $\mathrm{Rp}$ 32.701.000.000.000. Standar deviasi sebesar Rp 2.754.051.446.723,727 (di atas rata-rata) artinya pendapatan bersih memiliki tingkat variasi data yang tinggi.

Rata-rata jumlah karyawan yang dimiliki perusahaan sampel adalah 4.860 orang berarti secara keseluruhan perusahaan telah tergolong perusahaan besar menurut Badan Pusat Statistik, dimana jumlah karyawan harus diatas 100 orang. PT Saratoga Investama Sedaya Tbk memiliki jumlah karyawan terkecil sebanyak 52 karyawan pada tahun 2016 dan 2017. Jumlah karyawan terbesar sebanyak 225.580 karyawan dimana dimiliki perusahaan PT Astra International Tbk di tahun 2014. Standar deviasi jumlah karyawan adalah sebesar 13.802 orang (di atas rata-rata) artinya jumlah karyawan memiliki tingkat variasi data yang tinggi.

Berdasarkan tabel 1 memperlihatkan pengukuran leverage dideskripsikan dari debt to asset ratio dan debt to equity ratio.

Rata-rata DAR yakni 0,6089 yang artinya adalah nilai DAR perusahaan besar di Indonesia dapat diterima karena berada di nilai normal rasio yang biasanya bernilai 0,6 hingga 0,7 kali. PT Victoria Investama Tbk memiliki nilai DAR terkecil sebesar 0,0008 di tahun 2017, nilai DAR yang kecil diartikan bahwa pendanaan dengan utang semakin sedikit, maka semakin mudah bagi perusahaan untuk mendapatkan tambahan pinjaman karena perusahaan mampu menutupi utangutangnya dengan aset yang dimilikinya. PT Trikomsel Oke Tbk memiliki nilai DAR terbesar 16,8344 di tahun 2016. Demikian pula apabila nilai rasio DAR tinggi, semakin besar perusahaan dibiayai dengan utang, perusahaan dengan utang yang besar maka kemungkinan perusahaan tersebut mengalami masalah keuangan yang mengarah pada kepailitan. Nilai standar deviasi DAR adalah sebesar 0,7314 (di atas rata-rata), artinya DAR memiliki tingkat variasi data yang tinggi.

Rata-rata DER adalah 1,9536 yang artinya adalah nilai DER perusahaan besar di Indonesia dapat diterima karena berada di nilai normal rasio yang biasanya bernilai 1,5 hingga 2 kali. DER terkecil terdapat di tahun 2014 pada perusahaan PT Merck Sharp Dohme Pharma Tbk yakni sebesar 31,1754, DER negatif ini dikarenakan di tahun tersebut perusahaan mengalami defisiansi modal yang menyebabkan nilai dari ekuitas menjadi negatif. Demikian pula PT SLJ Global Tbk memiliki nilai DER terbesar 94,0997 di tahun 2017. DER tinggi berarti jumlah dari total liabilitas semakin besar dibandingkan dengan total ekuitasnya, yang menyebabkan beban perusahaan semakin besar terhadap pihak luar atau kreditur. Nilai standar deviasi DER adalah sebesar 4,0119 (di atas ratarata), artinya DER memiliki tingkat variasi data yang tinggi.

Berdasarkan tabel 1 yang telah diuraikan di atas memperlihatkan pengukuran profitabilitas dideskripsikan dari return on equity, return on asset, return on sales.

Rata-rata ROE adalah 0,0850, hal ini menunjukkan nilai mendekati 0 yang artinya perusahaan besar di Indonesia belum bisa mengelola ekuitas yang ada secara efesien untuk mendapatkan laba. PT Central Proteina Prima Tbk memiliki nilai ROE terkecil di tahun 2016 yaitu sebesar 11,0404. Nilai ROE yang kecil ini mengindikasikan bahwa perusahaan tidak menggunakan dana investor secara efesien, karena pada tahun tersebut perusahaan mengalami net loss. Demikian pula, PT Matahari Department Store Tbk memiliki nilai ROE terbesar yaitu 7,9910 di tahun 2014. Nilai ROE yang besar ini menunjukkan semakin tinggi nilai perusahaan bagi pemegang saham 
sehingga mereka tertarik untuk menanamkan modalnya diperusahaan tersebut. Nilai standar deviasi ROE adalah sebesar 0,4856 (di atas rata-rata) artinya ROE memiliki tingkat variasi data yang tinggi.

Rata-rata ROA adalah 0,0220, hal ini menunjukkan nilai mendekati 0 yang artinya perusahaan besar di Indonesia belum mampu mengelola aset yang tersedia secara efektif untuk menghasilkan laba. PT Trikomsel Oke Tbk memiliki nilai ROA terkecil sebesar $-10,8894$ di tahun 2015. Nilai ROA yang kecil ini artinya perusahaan tidak tepat sasaran dalam pengelolaan asetnya sehingga keuntungan yang didapat perusahaan juga tidak maksimal, karena rasio ini difungsikan untuk mengetahui seberapa efesiensinya perusahaan dalam mengubah uang yang dipakai untuk membeli aset menjadi net income, sedangkan pada tahun tersebut perusahaan mengalami net loss. Nilai ROA terbesar terdapat pada perusahaan PT Wintermar Offshore Marine Tbk pada tahun 2017 yaitu sebesar 1,1856. Demikian pula apabila nilai ROA tinggi, memperlihatkan bahwa perusahaan telah efesien dalam pengelolaaan aset yang dimilikinya untuk mendapatkan jumlah net income yang lebih besar. Nilai standar deviasi ROA adalah sebesar 0,3344 (di atas rata-rata), artinya ROA memiliki tingkat variasi data yang tinggi.

Rata-rata ROS adalah 0,0102 hal ini menunjukkan nilai mendekati 0 yang artinya perusahaan besar di Indonesia dalam mengoperasikan bisnis kurang baik untuk menghasilkan laba perusahaan. PT Bara Jaya Internasional Tbk memiliki nilai ROS terkecil sebesar $-28,2307$ di tahun 2016. Nilai ROS yang kecil ini menandakan kemungkinan akan terjadi permasalahan keuangan di perusahaan tersebut dan mengindikasikan manajemen kurang baik dalam mengoperasikan bisnis perusahaan. PT Greenwood Sejahtera Tbk memiliki nilai ROS terbesar di tahun 2015 yaitu sebesar 15,0928. Nilai ROS yang tinggi menunjukkan kinerja perusahaan yang semakin efisien, karena semakin tinggi rasio ROS maka semakin banyak keuntungan yang dihasilkan oleh perusahaan. Nilai standar deviasi ROS adalah sebesar 1,1981 (di atas rata-rata), artinya ROS memiliki tingkat variasi data yang tinggi.

Berdasarkan tabel 1 di atas umur perusahaan memiliki nilai rata-rata yaitu 35 tahun. Umur perusahaan dalam perusahaan sampel memiliki nilai terkecil 4 tahun yaitu pada perusahaan PT Cardig Aero Services Tbk, nilai minimum umur perusahaan ini didapat dari tahun penelitian yaitu 2013 dikurangi tahun perusahaan didirikan yaitu pada tanggal 16 Juli 2009. PT Telekomunikasi Indonesia (Persero) Tbk memiliki nilai umur perusahaan terbesar yaitu 161 tahun, nilai maksimum umur perusahaan ini didapat dari tahun penelitian yaitu 2017 dikurangi tahun perusahaan didirikan yaitu pada tanggal 23 Oktober 1856. Nilai standar deviasinya sebesar 18 tahun (di bawah rata-rata), artinya umur perusahaan memiliki tingkat variasi data yang rendah.

Berdasarkan tabel 1 yang telah diuraikan di atas, kepemilikan dispersi memiliki nilai rata-rata yaitu 0,2643. Kepemilikan dispersi memiliki nilai terkecil sebesar 0 dikarenakan terdapat beberapa perusahaan yang belum mengedarkan saham individunya pada tahun awal penelitian atau tidak sama sekali mengedarkan sahamnya ke publik. PT Sigmagold Inti Perkasa Tbk memiliki nilai kepemilikan dispersi terbesar 0,9986, nilai ini didapat dari perbandingan jumlah saham individu 5.494.583.747 terhadap jumlah saham beredar 5.502.083.747 di tahun 2017. Nilai standar deviasi kepemilikan dispersi adalah sebesar 0,1798 (di bawah rata-rata) yang berarti kepemilikan dispersi memiliki tingkat variasi data yang rendah. 
Tabel 2

Dummy Descriptive Statistics Results

\begin{tabular}{|c|c|c|c|c|c|}
\hline & & Frekuensi & Persentase & Persentase Valid & Persentase kumulatif \\
\hline \multirow[t]{3}{*}{ Valid } & Lainnya & 1690 & 81,6 & 81,6 & 81,6 \\
\hline & $\begin{array}{l}\text { Keuangan, TIK, } \\
\text { Energi }\end{array}$ & 380 & 18,4 & 18,4 & 100,0 \\
\hline & Total & 2070 & 100,0 & 100,0 & \\
\hline
\end{tabular}

Sumber: Data sekunder diolah (2019)

Tabel 2 menjelaskan sektor industri selama tahun 2013-2017 pada 414 perusahaan terdapat 1690 data atau $81,6 \%$ pengamatan perusahaan yang tidak termasuk sektor yang bergerak di bidang keuangan, Teknologi Informasi dan

Tabel 3

Dummy Descriptive Statistics Results

\begin{tabular}{|c|c|c|c|c|c|}
\hline & & Frekuensi & Persentase & Persentase Valid & Persentase kumulatif \\
\hline \multirow[t]{3}{*}{ Valid } & Non Big 4 & 1156 & 55,8 & 55,8 & 55,8 \\
\hline & Big 4 & 914 & 44,2 & 44,2 & 100,0 \\
\hline & Total & 2070 & 100,0 & 100,0 & \\
\hline
\end{tabular}

Sumber: Data sekunder diolah (2019)

Tabel 3 menjelaskan tipe auditor selama tahun 2013 hingga 2017 pada 414 perusahaan terdapat 1156 atau 55,8 \%
Komunikasi (TIK), dan energi. Terdapat 380 data atau $18,4 \%$ pengamatan perusahaan yang merupakan sektor yang bergerak di bidang keuangan, Teknologi Informasi dan Komunikasi (TIK), dan energi.

Tabel 4

Dummy Descriptive Statistics Results

\begin{tabular}{llrrrr}
\hline & Frekuensi & Persentase & Persentase Valid & Persentase kumulatif \\
\hline \multirow{2}{*}{ Valid } & Non IFR & 175 & 8,5 & 8,5 & 8,5 \\
& IFR & 1895 & 91,5 & 91,5 & 100,0 \\
& & & & \\
& Total & 2070 & 100,0 & 100,0 & \\
\hline
\end{tabular}

Sumber: Data sekunder diolah (2019)

Tabel 4 menjelaskan variabel dependen yaitu Internet Financial Reporting selama tahun 2013 hingga 2017 pada 414 perusahaan terdapat 175 atau $8,5 \%$ pengamatan perusahaan yang tidak pengamatan perusahaan yang diaudit KAP non big 4 dan 914 atau 44,2\% pengamatan perusahaan yang diaudit oleh KAP big 4 . 


\section{Analisis Regeresi Logistik}

Menurut Ghozali (2005) berikut penjabaran tahapan pengujian dengan memakai uji regresi logistik, yaitu

\section{Analisis Hipotesis}

\section{Tabel 5}

Hasil Uji Overall Model Fit/Omnibus Test

\begin{tabular}{llccr}
\hline & Chi-square & Df & Sig. \\
\hline Step 1 & Step & 118,918 & 12 &, 000 \\
& Block & 118,918 & 12 &, 000 \\
& Model & 118,918 & 12 &, 000 \\
\hline
\end{tabular}

Sumber: Data sekunder diolah (2019)

Tabel 5 merupakan tampilan dari tabel Chi-Square sebesar 118,918 dengan Df 12. Sig. Model sebesar 0,000 menunjukkan nilai $<5 \%$ maka dapat ditarik kesimpulan bahwa variabel independen

Tabel 6

Hasil Uji Wald yang digunakan dalam penelitian secara bersama-sama dapat mempengaruhi praktik Internet Financial Reporting.

\begin{tabular}{llrrrrrr}
\hline & \multicolumn{1}{c}{ B } & \multicolumn{1}{c}{ S.E. } & Wald & Df & \multicolumn{1}{c}{ Sig. } & Exp(B) \\
\hline $\begin{array}{l}\text { Step } \\
1^{a}\end{array}$ & Aset &, 000 &, 000 &, 582 & 1 &, 446 & 1,000 \\
& Pendapatan bersih &, 000 &, 000 & 1,678 & 1 &, 195 & 1,000 \\
Karyawan &, 000 &, 000 & 11,039 & 1 &, 001 & 1,000 \\
DAR &, 049 &, 123 &, 158 & 1 &, 691 & 1,050 \\
DER &,- 019 &, 017 & 1,310 & 1 &, 252 &, 981 \\
ROE &, 224 &, 133 & 2,809 & 1 &, 094 & 1,251 \\
ROA &,- 239 &, 505 &, 224 & 1 &, 636 &, 787 \\
ROS &,- 025 &, 073 &, 122 & 1 &, 727 &, 975 \\
Umur &,- 029 &, 004 & 42,499 & 1 &, 000 &, 971 \\
Kepemilikan dispersi &,- 069 &, 448 &, 024 & 1 &, 877 &, 933 \\
Sektor industri & $-1,455$ &, 358 & 16,551 & 1 &, 000 &, 233 \\
Tipe auditor &,- 908 &, 202 & 20,124 & 1 &, 000 &, 403 \\
Constant & 5,059 &, 449 & 127,126 & 1 &, 000 & 157,382 \\
\hline
\end{tabular}

a. Variable(s) entered on step 1: Aset, Pendapatan bersih, Karyawan, DAR, DER, ROE, ROA, ROS, Umur, Kepemilikan dispersi, Sektor industri, Tipe auditor.

Sumber: Data sekunder diolah (2019) 
Dari hasil uji wald dapat membentuk model regresi logistik biner seperti:

$$
\begin{gathered}
\operatorname{Ln} \frac{I F R}{1-I F R}=5,059+0,000 \text { Size }-0,029 \text { Age }- \\
\text { 1,455 Sect }- \text { 0,908 Aud }+\mathrm{e}
\end{gathered}
$$

Keterangan:

IFR : Dummy (IFR atau NIFR)

$\alpha \quad$ : Konstanta

Size : Ukuran perusahaan (karyawan)

Aud : Dummy (KAP Big 4 atau non Big 4)

Sect : Sektor industri

Age : Umur perusahaan

e : error

\section{a. Hasil Pengujian Hipotesis $1\left(\mathrm{H}_{1}\right)$}

Berdasarkan tabel 6 menunjukkan pengujian ukuran perusahaan yang dideskripsikan dari total aset dan pendapatan bersih tidak memiliki pengaruh signifikan dengan kemungkinan perusahaan menerapkan praktik Internet Financial Reporting, dikarenakan secara keseluruhan aset dan pendapatan bersih pada sampel penelitian telah tergolong perusahaan besar menurut Badan Standarisasi Nasional (BSN), sehingga investor atau calon investor tidak merasa ragu dan telah mengetahui kualitas perusahaan yang akan mereka investasikan.

Namun terdapat pengaruh signifikan antara jumlah karyawan dengan Internet Financial Reporting, diketahui bahwa jumlah karyawan pada sampel penelitian memiliki jumlah di atas ratarata, menunjukkan perusahaan besar di Indonesia memiliki jumlah karyawan yang sangat banyak, yang berdampak pada para karyawan yang menginvestasikan sahamnya ditempat mereka bekerja ingin mengetahui keadaan keuangan perusahaan sehingga mendorong perusahaan untuk menerapkan praktik Internet Financial Reporting. Hal ini menjelaskan bahwa hipotesis pertama diterima dengan menggunakan pengukuran jumlah karyawan. Hasil signifikansi ini sesuai dengan penelitian (Dolinšek \& LutarSkerbinjek, 2017). b. Hasil Pengujian Hipotesis $2\left(\mathrm{H}_{2}\right)$

Berdasarkan tabel 6 menunjukkan variabel leverage yang diukur menggunakan DAR maupun DER tidak memiliki pengaruh signifikan terhadap kemungkinan perusahaan menerapkan praktik Internet Financial Reporting. Dari kedua pengukuran tersebut tidak ada yang memperlihatkan hasil yang signifikan, hal ini menjelaskan bahwa hipotesis kedua ditolak, karena perusahaan besar dengan tingkat yang tinggi atau rendah pada leverage cenderung akan tetap menggunakan praktik IFR. Hasil tidak signifikan ini sesuai dengan penelitian (Al Arussi et al., 2009; Aly et al., 2010; Xiao et al., 2004; Oyelere et al., 2003).

c. Hasil Pengujian Hipotesis $3\left(\mathrm{H}_{3}\right)$

Berdasarkan tabel 6 menunjukkan pengukuran profitabilitas dideskripsikan dari ROE, ROA, dan ROS tidak berpengaruh signifikan dengan IFR. Ketiga pengukuran yang diuji tidak ada yang membuktikan hasil signifikan positif terhadap kemungkinan perusahaan menerapkan praktik Internet Financial Reporting. Dijelaskan bahwa hipotesis ketiga ditolak, dikarenakan perusahaan besar yang berada di Indonesia baik perusahaan yang melakukan praktik IFR atau non IFR akan memberikan informasi mengenai profitabilitas dalam pelaporan keuangan melalui internet. Hasil tidak signifikan ini sesuai dengan penelitian (Al Arussi et al., 2009; Alanezi, 2009; Nurunnabi \& Hossain, 2012; Suripto, 2006).

\section{d. Hasil Pengujian Hipotesis $4\left(\mathrm{H}_{4}\right)$}

Berdasarkan tabel 6 menunjukkan umur perusahaan berpengaruh signifikan negatif dengan penerapan praktik Internet Financial Reporting. Dijelaskan bahwa hipotesis keempat ditolak, yang beranggapan bahwa umur perusahaan yang berumur lebih lama justru melakukan praktik IFR yang kecil atau sebaliknya. Tidak ditemukan hasil penelitian yang sependapat yang mengemukakan bahwa 
umur perusahaan berpengaruh signifikan negatif dengan IFR.

\section{e. Hasil Pengujian Hipotesis $5\left(\mathrm{H}_{5}\right)$}

Berdasarkan tabel 6 menunjukkan variabel kepemilikan dispersi tidak berpengaruh signifikan dengan kemungkinan perusahaan menerapkan Internet Financial Reporting. Hal ini menjelaskan bahwa hipotesis kelima ditolak, perusahaan yang memiliki kepemilikan dispersi dan perusahaan yang memiliki kepemilikan terkonsentrasi cenderung akan tetap melakukan praktik IFR atau menyebarluaskan informasi keuangan yang lengkap mengenai keadaan keuangan perusahaan. Hasil tidak signifikan ini sesuai dengan (Alanezi, 2009; Xiao et al., 2004).

\section{f. Hasil Pengujian Hipotesis $6\left(\mathrm{H}_{6}\right)$}

Tabel 6 yang telah diuraikan di atas menunjukkan variabel sektor industri berpengaruh signifikan negatif dengan penerapan praktik IFR. Dijelaskan bahwa hipotesis keenam ditolak, yang beranggapan bahwa sektor industri

\section{Uji Koefisien Determinasi (Nagelkerke R Square)}

\section{Tabel 7}

Hasil uji koefisien determinasi (Nagelkerke R Square)

\begin{tabular}{cccc}
\hline Step & $\mathbf{- 2}$ Log likelihood & Cox \& Snell R Square & Nagelkerke R Square \\
\hline 1 & $1081,159^{\mathrm{a}}$ &, 056 &, 127 \\
\hline
\end{tabular}

a. Estimation terminated at iteration number 8 because parameter estimates changed by less than ,001.

Sumber: Data sekunder diolah (2019)

Berdasarkan tabel 7 Nilai

Nagelkerke $R$ Square sebesar 0,127 menunjukkan kekuatan dari variabel bebas dalam menerangkan variabel terikat adalah berteknologi tinggi pada perusahaan besar di Indonesia justru melakukan praktik IFR yang kecil. Hasil signifikan negatif ini sesuai dengan penelitian (Nurunnabi \& Hossain, 2012).

\section{g. Hasil Pengujian Hipotesis $7\left(\mathrm{H}_{7}\right)$}

Berdasarkan tabel 6 menunjukkan variabel tipe auditor berpengaruh signifikan negatif dengan penerapan praktik Internet Financial Reporting. Hal ini menjelaskan bahwa hipotesis ketujuh ditolak, disebabkan karena perusahaan audit big 4 telah memiliki hasil audit yang berkualitas baik sehingga memberikan dampak kepercayaan investor. Tidak ditemukan hasil penelitian yang sependapat yang mengemukakan tipe auditor berpengaruh signifikan negatif dengan IFR.

\section{Uji Kelayakan Model Regresi (Hosmer and Lemeshow Test)}

Tabel 8

Hasil uji kelayakan model regresi (Hosmer and Lemeshow Test)

\begin{tabular}{|c|c|c|c|}
\hline \multicolumn{1}{c}{ Step } & Chi-square & \multicolumn{1}{c}{ Df } & Sig. \\
\hline 1 & 2,583 & 8 &, 958 \\
\hline
\end{tabular}

Sumber: Data sekunder diolah (2019) 
Berdasarkan tabel 8, nilai Hosmer and Lemeshow Test sebesar Sig. 0,958 $(>0,05)$ yang memperlihatkan model yang dipakai untuk mengetahui hasil dari dilakukannya penelitian ini dapat diterima karena model mampu memperkirakan nilai observasinya.

\section{Uji Multikolinearitas}

Tabel 9

Hasil uji multikolinearitas

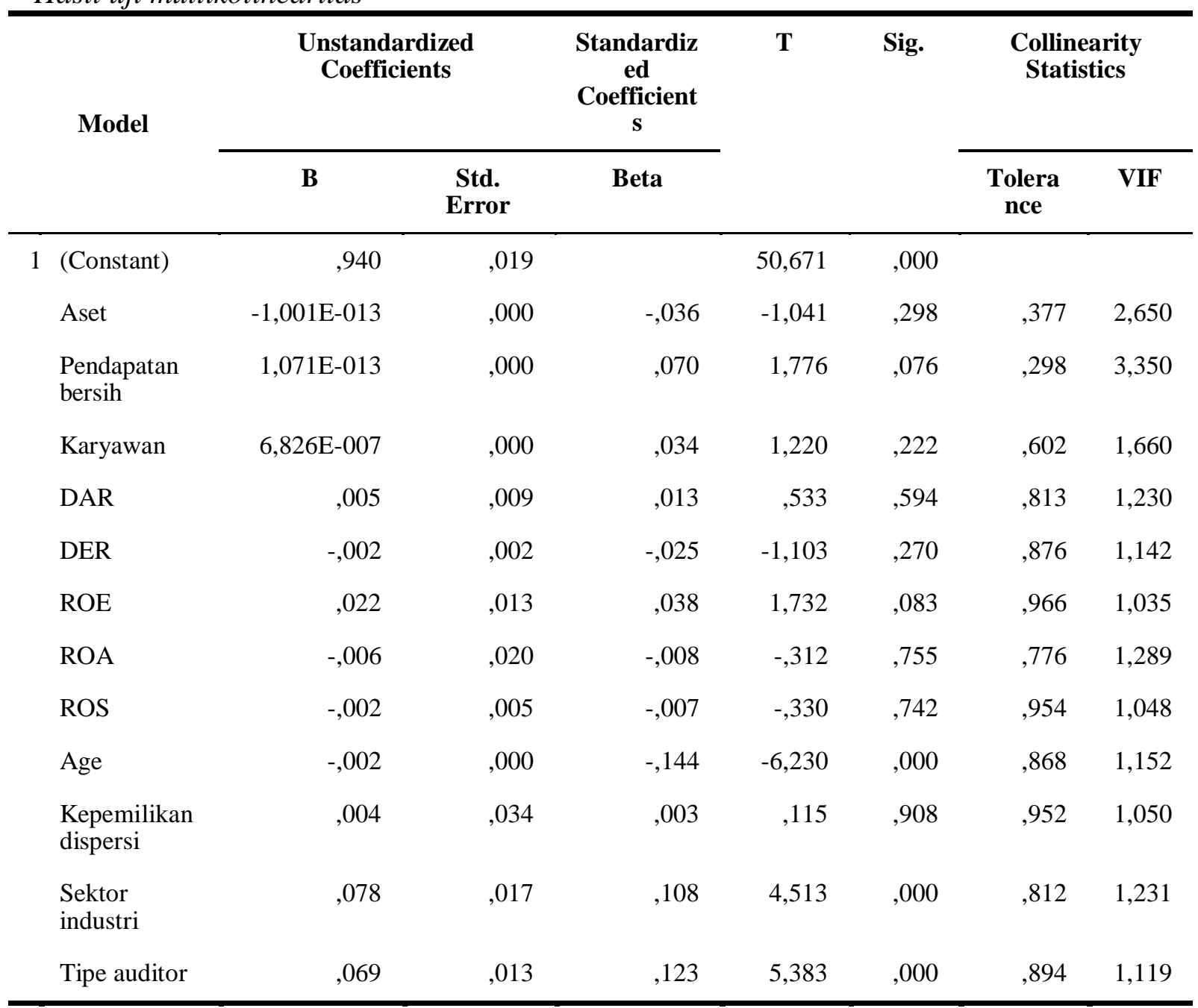

a. Dependent Variable: IFR

Sumber: Data sekunder diolah (2019)

Tabel 9 menunjukkan model regresi dapat dikatakan baik karena seluruh variabel bebasnya tidak ada nilai VIF $>10$, artinya regresi ini tidak ada gejala korelasi yang kuat di antara variabel independennya. Sehingga, tidak perlu mengeluarkan salah satu variabel bebas yang memiliki korelasi yang tinggi dari model regresi dan mengidentifikasi variabel lainnya untuk membantu prediksi menanggulangi jika terjadi multikolinearitas. 
Uji Matriks Klasifikasi

Tabel 10

Hasil uji matriks klasifikasi

\begin{tabular}{llrrrr}
\hline & Observed & \multicolumn{3}{c}{ Predicted } \\
\cline { 3 - 5 } & & \multicolumn{3}{c}{ IFR } & Percentage Correct \\
\cline { 3 - 4 } & & Non IFR & IFR & \\
\hline Step 1 & IFR & Non IFR & 3 & 172 & 1,7 \\
& IFR & 0 & 1895 & 100,0 \\
& & & & 91,7 \\
\hline
\end{tabular}

a. The cut value is ,500

Sumber: Data sekunder diolah (2019)

Tabel 10 menunjukkan bahwa penggunaan model regresi logistik telah cukup baik, dikarenakan telah mampu memprediksi dengan benar 91,7\% kondisi yang terjadi. Matriks klasifikasi

\section{CONCLUSION}

Tujuan penelitian ini untuk meneliti tentang faktor-faktor yang sesuai dengan perusahaan mana mempublikasikan pengungkapan informasi keuangan secara sukarela di situs mereka (perusahaan IFR) dengan perusahaan yang tidak mempublikasikan informasi keuangannya (perusahaan NIFR). Penelitian sebanyak 414 perusahaan besar yang terdaftar di Bursa Efek Indonesia tahun 2013-2017, menemukan bahwa 91,5\% atau 1895 data yang melakukan praktik IFR dan $8,5 \%$ atau 175 data yang tidak melalukan praktik IFR.

Ukuran perusahaan yang dideskripsikan dari aset dan pendapatan bersih tidak berpengaruh signifikan terhadap IFR, namun terdapat signifikan ormasi keuangan yang lengkap mengenai keadaan keuangan perusahaan, yang beranggapan bahwa perusahaan memiliki tanggung jawab yang besar untuk memenuhi kebutuhan informasi yang dibutuhkan pihak luar dan juga untuk menjaga kepercayaan investor terhadap perusahaan. menunjukan kemampuan memprediksi dari model regresi untuk mengetahui kemungkinan perusahaan menerapkan praktik Internet Financial Reporting.

positif jika diukur menggunakan jumlah karyawan. Secara keseluruhan sampel telah tergolong perusahaan besar, sehingga investor atau calon investor tidak merasa ragu dan telah mempercayai kualitas perusahaan yang akan mereka investasikan tanpa memfokuskan nilai aset dan pendapatn bersih, dan perusahaan besar memiliki jumlah karyawan yang sangat banyak berdampak pada para karyawan yang menginvestasikan sahamnya ditempat mereka bekerja ingin mengetahui keadaan keuangan perusahaan.

Leverage yang diukur menggunakan DAR dan DER tidak berpengaruh signifikan dengan Internet Financial Reporting, karena perusahaan besar dengan leverage tinggi atau rendah cenderung akan tetap menggunakan praktik IFR atau memberikan inf Profitabilitas dideskripsikan dari ROE, ROA, dan ROS. Ketiga pengukuran tidak berpengaruh signifikan dengan IFR, dikarenakan profitabilitas pada perusahaan besar yang memiliki rasio rendah maupun tinggi akan tetap menerapkan IFR yang bertujuan untuk menunjukkan keterbukaan manajemen perusahaan dalam melaporkan informasi keuangan perusahaan dan hal itu 
tidak akan menghambat perusahaan untuk melakukan praktik IFR.

Umur perusahaan memiliki pengaruh signifikan negatif terhadap Internet Financial Reporting, yang beranggapan umur perusahaan yang berumur lebih lama justru melakukan praktik IFR yang kecil atau sebaliknya, dikarenakan perusahaan yang telah lama berdiri terutama pada perusahaanperusahaan besar telah mampu menjalankan dan mengelola bisnisnya dengan baik, sehingga memberikan dampak pada kepercayaan investor kepada perusahaan.

Kepemilikan dispersi tidak memiliki pengaruh terhadap Internet Financial Reporting, dikarenakan kepemilikan saham baik dispersi maupun terkonsentrasi yang dimiliki perusahaan besar, pemilik saham oleh investor individu akan meminta pengungkapan lebih untuk memantau perilaku manajemen, sehingga manajemen pada perusahaan besar bertanggung jawab untuk memenuhi kebutuhan informasi yang dibutuhkan investor individu terhadap perusahaan dengan melakukan praktik IFR.

Sektor industri berpengaruh signifikan negatif IFR, dikarenakan perusahaan besar di Indonesia mayoritas diluar sektor yang berteknologi tinggi seperti pada perusahaan yang bergerak pada sektor agrikultur, perdagangan, jasa dan investasi, properti, makanan dan minuman, dan lain sebagainya, karena aktivitas bisnis mereka tidak terhubung dengan informasi teknologi, maka mereka tidak rentan terhadap praktik Internet Financial Reporting.

Tipe auditor berpengaruh signifikan negatif terhadap Internet Financial Reporting, dikarenakan tipe auditor yang termasuk perusahaan berafiliasi dengan audit big 4 telah memiliki kualitas audit yang baik memberikan dampak pada kepercayaan investor kepada perusahaan.

Keterbatasan penelitian ini yakni kekuatan variabel bebas dalam menjelaskan variabel terikat yang dapat dilihat pada uji Nagelkerke $R$ Square dalam sebuah penelitian ini masih kecil yaitu $12,7 \%$. Hal itu menunjukkan bahwa masih terdapat faktor lain diluar model regresi pada penelitian ini yang dapat menjelaskan variabel terikatnya, seperti likuiditas, independensi direktur, $C E O$ role duality, resiko sistematis, pasar saham, kecukupan modal, kekayaan kota, tipe kebijakan lokal, tekanan visibilitas, pengembalian saham, prospek pertumbuhan, karakteristik lingkungan, tata kelola perusahaan, dan lain sebagainya.

Rekomendasi yang dapat diberikan yakni penelitian mendatang agar dapat memperluas sampel penelitian baik dengan menambah tahun penelitian, melakukan penelitian dengan sampel dari negara lain, melakukan perbandingan tingkat Internet Financial Reporting antar dua negara yang berbeda, dan diharapkan penelitian mendatang agar dapat menambah variabel bebas lain di luar penelitian ini.

\section{REFERENCES}

Al-Moghaiwli, M. H. (2009). A survey of internet financial reporting in Qatar. Journal of Economic and Administrative Sciences, 25(1), 1-20. https://doi.org/10.1108/102641162009 00001

Al Arussi, A. S., Selamat, M. H., \& Mohd Hanefah, M. (2009). Determinants of financial and environmental disclosures through the internet by Malaysian companies. Asian Review of Accounting, 17(1), 59-76. https://doi.org/10.1108/132173409109 56513

Alanezi, F. S. (2009). Factors influencing Kuwaiti companies' internet financial reporting. Journal of Economic and Administrative Sciences, 25(2), 1-23. https://doi.org/10.1108/102641162009 00007

Alsaeed, K. (2006). The association between firm-specific characteristics 
and disclosure: The case of Saudi Arabia. Managerial Auditing Journal, $21(5)$, 476-496. https://doi.org/10.1108/026869006106 67256

Aly, D., Simon, J., \& Hussainey, K. (2010). Determinants of corporate internet reporting: Evidence from Egypt. Managerial Auditing Journal, 25(2),

182-202. https://doi.org/10.1108/026869010110 08972

Bollen, L., Hassink, H., \& Bozic, G. (2006). Measuring and explaining the quality of internet investor relations activities: a multinational empirical analysis. International Journal of Accounting Information Systems, 7(4), 273-298.

https://doi.org/10.1016/j.accinf.2006.0 4.005

Bowrin, A. R. (2015). Comprehensiveness of internet reporting by Caribbean companies. Journal of Accounting in Emerging Economies, 5(1), 2-34. https://doi.org/10.1108/JAEE-082011-0028

Dolinšek, T., \& Lutar-Skerbinjek, A. (2017). Voluntary disclosure of financial information on the internet by large companies in Slovenia. Kybernetes, 47(3), 458-473. https://doi.org/10.1108/K-08-20160220

Ghozali, I. (2005). Aplikasi analisis multivariate dengan program SPSS (III). Semarang: Universitas Diponegoro.

Hossain, M., \& Hammami, H. (2009). Voluntary disclosure in the annual reports of an emerging country: The case of Qatar. Advances in Accounting, Incorporating Advances in International Accounting, 25, 255265.

https://doi.org/10.1016/j.adiac.2009.08 .002

Khan, M. N. A. A., \& Ismail, N. A. (2012). Users' perceptions of various aspects of Malaysian internet financial reporting. The Journal of Organizational Management Studies, 2012, 1-14. https://doi.org/10.5171/2012.852558

Lestari, H. S., \& Chariri, A. (2007). Analisis faktor-faktor yang mempengaruhi pelaporan keuangan melalui internet (internet financial reporting) dalam website perusahaan. Jurnal Akutansi, 0-27. Retrieved from https://www.researchgate.net/publicati on $/ 277851653 \% 0 \mathrm{~A}$

Marston, C. (2003). Financial reporting on the internet by leading Japanese companies. Corporate Communications: An International Journal, $\quad 8(1), \quad 23-34$. https://doi.org/10.1108/135632803104 58894

Marston, C., \& Polei, A. (2004). Corporate reporting on the internet by German companies. International Journal of Accounting Information Systems, 5, 285-311.

https://doi.org/10.1016/j.accinf.2004.0 2.009

Mohamed, E. K. ., \& Basuony, M. A. K. (2015). Voluntary internet disclosures by listed companies in the Arabian gulf. International Business and Economyusiness and Economy, 5(8). https://doi.org/10.2139/ssrn.2549759

Mokhtar, E. S. (2017). Internet financial reporting determinants: a metaanalytic review. Journal of Financial Reporting and Accounting, 15(1), 116-154. https://doi.org/10.1108/jfra07-2016-0061

Nurunnabi, M., \& Hossain, M. A. (2012). The voluntary disclosure of internet financial reporting (IFR) in an emerging economy: A case of digital Bangladesh. Journal of Asia Business Studies, 6(1), 17-42. https://doi.org/10.1108/155878912111 90688

Oyelere, P., Laswad, F., \& Fisher, R. (2003). Determinants of internet financial reporting by New Zealand 
companies. Journal of International Financial Management and Accounting, $\quad$ 14(1), 26-63. https://doi.org/10.1111/1467646X.00089

Pervan, I. (2006). Voluntary financial reporting on the internet-analysis of the practice of Croatian and Slovene listed joint stock companies. Financial Theory and Practice, 30(1), 1-27.

Sulistyanto, H. R., \& Nugrahanti, Y. W. (2013). Analisis perbedaan ketepatan waktu internet financial reporting pada perusahaan manufaktur yang terdaftar di BEI. Jurnal Dinamika Akuntansi, 5(2), 146-156. Retrieved from http://journal.unnes.ac.id/nju/index.ph $\mathrm{p} / \mathrm{jda}$

Suripto, B. (2006). Pengaruh besaran profitabilitas, pemilikan saham oleh publik, dan kelompok industri terhadap tingkat pengungkapan informasi keuangan dalam website perusahaan. Jurnal Akuntansi Dan Keuangan.

Xiao, J. Z., Yang, H., \& Chow, C. W. (2004). The determinants and characteristics of voluntary internetbased disclosures by listed Chinese companies. Journal of Accounting and Public Policy, 23, 191-225. https://doi.org/10.1016/j.jaccpubpol.20 04.04.002 